\title{
Postcolonialism and social exclusion of indigenous people in Mexico
}

\author{
Pós-colonialismo e exclusão social de indigenas no México
}

\section{Nubia Nieto}

\begin{abstract}
During the last decade, Mexico has experienced high levels of violence, and one of the most vulnerable groups has been the indigenous people. In this context, the present text aims to analyse the relationship between the legacies of colonialism and social exclusion of indigenous people in Mexico. The text is divided into three parts. The first part describes the main historical lines of the discrimination against the indigenous people. The second considers the factors that have contributed to institutionalize, accept and reproduce social and economic inequality. The third discusses the complexities of the social imaginary, which strengthen the discrimination. Finally, some comments to reduce inequality in Mexico.
\end{abstract}

\section{Keywords}

Postcolonialism; Mexico; Inequality; Indigenous People; Mestizos.

\section{Resumo}

Durante a última década, o México experimentou altos níveis de violência e um dos grupos mais vulneráveis tem sido o povo indígena. Neste contexto, o presente texto pretende analisar a relação entre os legados do colonialismo e a exclusão social dos indígenas no México. $\mathrm{O}$ texto é dividido em três partes. A primeira parte descreve as principais linhas históricas da discriminação contra os povos indígenas. $\mathrm{O}$ segundo considera os fatores que contribuíram para institucionalizar, aceitar e reproduzir a desigualdade social e econômica. O terceiro discute as complexidades do imaginário social que fortalecem a discriminação. Finalmente, alguns comentários para reduzir a desigualdade no México.

\section{Palavras-chave}

Pós-colonialismo; México; Desigualdade; Indígenas; Mestiços. 


\section{Introduction}

From the discovery of Mexico until our times, Mexico continue dragging the chains of the past, and one of the most painful legacies of colonialism in Mexico is the inequality ${ }^{1}$ and social exclusion of the indigenous people, which has been a constant since Mexico was colonized by the Spaniards in 1521. This legacy has condemned the indigenous people to live in misery, servitude, humiliation, ignorance, sexual exploitation, and constant abuse of the human rights.

In this context, the present text aims to analyse the relationship the legacies of colonialism and social exclusion of the indigenous people in Mexico, since they are crucial in understanding the inequalities existing in Mexico today, inequalities that risk being perpetuated. The text is divided into three parts plus the final comments. The first part describes the main historical lines of discrimination against the indigenous people and the supremacy of the European and North America people, as well as mestizos. The second part considers the factors that have contributed to institutionalize, accept, and reproduce social and economic inequality among the indigenous people, such as the PRI and the state policies. The third part discusses the complexities of 'the social imaginary', which strengthen the discrimination against indigenous groups through the soap operas, films and media publicity. Finally, some comments are offered, which stress the need to diminish inequality amongst indigenous groups by ensuring the Mexican State respects the rule of law toward the most vulnerable people.

\footnotetext{
${ }^{1}$ Culture of poverty was first used by Oscar Lewis referring to a culture of marginal people who are not integrated into national institutions - including schools, political parties, trade unions, banks, hospitals, department stores, art galleries, etc. This rejection of these institutions is partly because poor people do not trust them, but also because they are often ineligible to join or cannot afford to use them. People who share the culture of poverty share a set of social and psychological characteristics: living in crowded quarters, lack of privacy, gregariousness, high incidence of alcoholism, frequent resort to violence in the settlement of quarrels, frequent use of physical violence in the training of children, wife beating, early initiation into sex, free unions or consensual marriages, high incidence of the abandonment of mothers and children, a tendency towards mother-centred families, a strong predisposition to authoritarianism, strong present-orientation - little ability to defer gratification, little planning for the future, a sense of resignation and fatalism, a belief in male superiority - machismo the cult of masculinity, corresponding martyr complex amongst women, a high tolerance for psychological pathology (LEWIS, 1961).
} 


\section{The roots of the inequality}

The colonization ${ }^{2}$ of the indigenous people ${ }^{3}$ in Mexico resulted in a division between those who were "colonizers" and those who were "colonized" and this manifested in different ways. In terms of race relations, it ushered in the caste system ${ }^{4}$ classifying people according to their ethnic and biological background. According to Eakin, the peninsular - a person born in Europe, whose parents were both European - was at the top of the social and economic hierarchy; the second group was the Creole - a person of mixed race, from European and indigenous background -, the creoles were also known as Mestizos or criollos; the third group were the indigenous people or Indians - both parents indigenous (EAKIN, 2007).

During the Spanish colonization of the Americas, beginning with Christopher Columbus in 1492, Spaniards brought with them the notion of limpieza de sangre, blood purity-, installing a racial hierarchy, which lasts to the present day.

According to Martínez, Limpieza de sangre is a Spanish creation and:

\footnotetext{
${ }^{2}$ Colonialism can be defined in this text as "the conquest and control of other people's land and goods (...) and as the takeover of territory, appropriation of material resources, exploitation of labour and interference with political and cultural structures of another territory or nation" (LOOMBA, 2015, p. 20-27). And Postcolonialism analyses how representations and articulations of colonial space did not come to an end at the time of decolonisation, but continued to be mobilised, reworked and mediated through ideologies, individuals and institutions in the post-independence period (KOTHARI, 2009) 3 This text adopts the definition by José R. Martinez Cobo, the special rapporteur of the SubCommission on Prevention of Discrimination and Protection of Minorities. He defines "Indigenous communities, peoples and nations are those which, having a historical continuity with pre-invasion and pre-colonial societies that developed on their territories, consider themselves distinct from other sectors of the societies now prevailing on those territories, or parts of them. They form at present nondominant sectors of society and are determined to preserve, develop and transmit to future generations their ancestral territories, and their ethnic identity, as the basis of their continued existence as peoples, in accordance with their own cultural patterns, social institutions and legal system" (MARTÍNEZ COBO, 1987, p.5)

${ }^{4}$ Caste system is used as a social system that combines some elements of ethnic background, hereditary occupation, social class, religious hierarchy and social identity, and it is defined at birth (YOUNG, 2003).
} 
It is a concept developed in 15th-century Spain, referring to a person without Jewish, Muslim or heretical ancestry. Purity of blood became an obsessive concern in Spain when persecuted Jews and Muslims began converting to Christianity in large numbers. Converts were dubbed New Christians and those claiming to have limpieza de sangre called themselves Old Christians (MARTÍNEZ, 2008, p. 25-26).

The idea of Limpieza de sangre was created to protect the old Christians faith. In the New World, Martínez says, the concept of Limpieza de sangre had profound repercussions for the populations that were subjected to Spanish rule. Spaniards did not officially label the indigenous people as "impure in blood", because the indigenous people had accepted Spanish rule and Christianity, therefore they were considered free Christian vassals of the Crown of Castile (MARTÍNEZ, 2008).

However, the Spaniards used the concept of "purity of blood" in the New World to explain their political and economic domination over indigenous people and justify their position of bringing indigenous people into the church's fold to save their souls (MARTÍNEZ, 2008). The descendants of the conquistadors, along with new arrivals from Spain, formed a new elite class in the country. Intermixing eventually produced a Mestizo group that would become the nation's demographic majority by the time of Independence. The Spaniards and mestizos, assumed the idea of superiority based on their biological and cultural roots rising to positions of power and prestige, unlike the indigenous people, who accepted the assumption of "inferiority".

Labelling vast numbers of people as inferior, or "other", was crucial for constructing a European "self" and justifying colonialist practices. The construction of social identities 5 based on ethnic background nourished a feeling of racism towards indigenous people and contributed to a division between those who were "winners and those who were losers". This was apparent in the intensive exploitation of the indigenous labour force, contributing to the creation of economic differences, social class divisions and the beginning of capitalism in Latin America. Colonialism was the means through which capitalism achieved its global expansion. Racism

\footnotetext{
${ }^{5}$ Social identities are understood as "sets of meanings that an actor attributes to itself while taking the perspective of others, that is, as a social object (...) Social identities are at once cognitive schemas that enable an actor to determine 'who I am/we are' in a situation and positions in a social role structure of shared understandings and expectations” (WENDT, 1994, p. 395).
} 
simply facilitated this process and provided the channel through which those goals were achieved (LOOMBA, 2015).

The colonial regime in Mexico introduced a system of casta or estamental society, in which the ethnic origin of a person would determine their position in the social hierarchy. This coincided perfectly with the economic needs of the Spaniards, and with their social system of hierarchization. Racial differences in the New Spain served to structure the class system, and the distribution of wealth, which still resonates today. According to Eakin (2007), white people not only had more advantages over the dark-skinned indigenous people, but also their social-economic background was reproduced in the new territory.

At the very top of the pyramid in Spanish America were those who truly were European, born in Spain called peninsulares, with wealth, education and excellent background, and political connections. Yet, a poor Spaniard, with no education, no money, and no social connection could also sink far down the social pyramid, but he would still have an advantage over his darkerskinned, colonized Indigenous people, who would be at the bottom of the pyramid (EAKIN, 2007, p. 138).

According to Alan Knight, the difference between the indigenous people and the Spanish people was that the Spaniards were racially identified with power and privilege, cultural and biological superiority, in which Europeans and mestizos enjoyed better access to power and property (KNIGHT, 1990). The economic structure imposed in Mexico by the Spanish colonizers was the system of encomienda, which means encomendar - to entrust-. This system entailed an authorisation by the Spanish Crown, usually for life, to collect labour and tribute from indigenous communities. A Corregidor or Alcande - Mayor -, local Spanish official, was in charge of a given jurisdiction, to oversee this process. The encomendero - the person in charge of-informed the cacique, -indigenous chief or local ruler -, of his demands, and the cacique depended on the already existing labour and tribute mechanisms to meet these demands (TERRACIANO, 2011).

Spanish encomenderos bullied and punished the cacique if he did not collect the require tributes. In this sense, the encomiendafacilitated not only the exploitation of the indigenous labour force, but also institutionalized their exploitation (TERRACIANO, 2011). 
The encomienda system granted its beneficiaries the right to extract tribute - usually under the form of labour - from the Indian population of a given region. An encomiendawas a highly-sought reward for the early conquistadors of the Aztec and Inca empires. The large abuses to which the system gave place led the Crown to attempt its regulation and demise from the early days of the Spanish Empire (ANGELES e NEANIDIS, 2010, p. 6).

Ferguson argues that since the arrival of Spanish conquerors in Latin America, land, wealth, and political representation have been controlled bya tiny elite. Under the encomienda system, the Spanish elite gained the right to exploit labour for the Crown; in the haciendas - large landholding allocated for plantations, mines, and factories -, the hacendados or patrones acquired the right to own land and control labour. The hacendados were the owners of the land, and the indigenous people worked as peones - farmer workers - on the land belonged to the patron-owner (FERGUSON, 2011).

The colonial process also brought about a radical socio-ecological transformation, introducing irreversible changes in the basin's hydrogeology and leading to the formation of an oligarchic social order where land and water became concentrated in the hands of a small elite with the displacement of the indigenous people from the best lands (CASTRO, 2016).

On the other hand, Eakin affirms that Mexico City was the largest urban centre in all of the Americas, with a population of nearly 170, 000 in 1810. Indians or indigenous people made up 60 percent of the population, another 20 percent were mixed race, and the other 20 percent were whites. European-born Spaniards probably numbered around 15,000 less than one-half of 1 percent of the population, but they controlled the political and administrative machinery of the viceroyalty. And by the end of the eighteenth century, Mexico provided Madrid with enormous profits and created the richest family fortunes in the Americas. At the same time, the masses suffered ten major famines in years before 1810 (EAKIN, 2007).

Racial superiority, political rule, economic power, land possession and social status were seen by the Peninsulares and the Mestizos as their "natural right". "Obedezco pero no cumplo" - I obey but will not comply - was used by the Peninsulars and Mestizos to delay or forego the implementation of certain Royal laws that conflicted with local interests or did not suit local elites. In this way, corruption became accepted, tolerated and institutionalized by the representatives of Mexican law (RAMÍREZ, 2011). 
Following the defeat of the Spanish Armada in 1588, the Crown tried to impose a special tax to sponsor and arm an American fleet. Town councils - Cabildo - representing the power and authority of the local elite began lobbying against the tax. In the end the Crown won, but corrupt practices began to infiltrate the Cabildo in an attempt to avoid paying the tax. As a case in point, Susan Ramírez affirms, the Supreme Court Judge, Bartolomé Salazar, a dangerous and greedy man, used his position to build a personal fortune of over $10.000,000$ pesos, which in the midseventeenth century was a huge fortune (RAMÍREZ, 2011).

Europeans held most of the positions of power and monopolized resources resulting in an unequal distribution of wealth between the elite and the vast majority of the population descended primarily from the conquered peoples. Peninsulares and mestizos controlled all means of production and extracted surplus products or labour from indigenous people. A small group of indigenous elites managed to adapt to colonial change, but most native men and women were confined to manual labour and menial tasks, in the fields, in the mines, or as transport workers, petty merchants, street vendors, and domestic servants (TERRACIANO, 2011).

The massive exploitation of indigenous people was reflected in the workshops that were controlled by foreigner owners and mestizos as Galeano underlines:

At the beginning of the nineteenth century Alexander Von Humboldt estimated the value of Mexican manufactures -mostly textiles- at some 7 or 8 million pesos. Woolen and cotton cloth were turned out in specialized workshops: Querétaro had more than 200 looms and 1,500 workers: 1,200 cotton weavers worked in Puebla (...) The industry was based on forced labour by Indians who were locked into the shops from before dawn till late at night" (GALEANO, 2009, p. 175-176).

On the other hand, Castro affirms that social, political, economic and ecological development was not reversed by independence movement (1811-1821), and it was intensified by the nineteenth-century process of state formation characterized by the building of liberal institutions in the Ibero-Indian territory. This period was marked by renewed confrontations between the communitarian and individualistic models of social organization that had been at work throughout colonial process. In the nineteenth century, corporate forms of land and water ownership and church possessions prevailing in the Indian villages, deepened the process of social exclusion (CASTRO, 2016). 


\section{Institutionalization of social exclusion}

The Mexican Independence and the Porfiriato - the rule of Porfirio Díaz, 1876-1911- did not solve the main problems inherited from the Colonial period (1521-1821) nor the social exclusion of indigenous people. In terms of cultural identity, Díaz imported the "French taste" as seen in the decoration of official houses and the fashion among Mexican Elites. The politicians of the Porfiriato were known as Científicos - educated bureaucrats -, who were formed in French universities and were influenced by Auguste Comte's philosophy of positivism. This philosophy glorifies order and progress through reason and scientific knowledge, rejecting traditional religious beliefs. Another exponent of positivism was Herbert Spencer, who believed in social Darwinism in which the human race evolves unevenly, leaving some inferiors to others (EAKIN, 2007).

The adoption of the positivism in Mexico justified the control under indigenous people, were considered "inferior", and empowered the elites with an entitlement to rule. Scientifically educated experts - technocrats -, contributed thus to maintain the gap between indigenous people, mestizos and American and European foreigners. Díaz's reputation as vendepatrias - a seller-out of his country was sealed by his support for government policies that favoured the elite at the expense of the indigenous people, who continued being over-exploited (KNIGHT, 2016). Under Porfirio Díaz, development and unbridled foreign investment, led to corruption at every level of the State (MEADE, 2010).

At the beginning of the $20^{\text {th }}$ century, American companies controlled the main Mexican industries. For example, in mining, the exploitation of copper, gold, silver, lead, and tin belonged to the Americans. They monopolized not only the property, but also the process of work and trade. Mexico's oil industry, which was by the end of the first decade of the new century the third largest in the world, was sold to the North American Rockefeller consortium. Wages and working conditions were terrible. Men and women left the land to take up urban jobs as factory labourers, where women earned a fraction of the salary paid to men. The typical workday was 12-15 hours long: men were paid 75 cents, women and children as little as 11 cents for a day's labour. Many were never paid in cash, instead receiving vouchers that could only be redeemed at the company store for food or housing in the company towns encircling the plants and mines (MEADE, 2010).

North American foreigners owned factories producing industrial quantities of alcohol, which the indigenous population were encouraged to consume. For example, the Pulque - a strong alcoholic drink made from the maguey cactus plant used 
among indigenous people mainly at festivities and ritual events-, was produced in large quantities along other cheap alcoholic beverages. In the midst of hunger, the number of bars in Mexico City rose from 51 in 1864 to 1,400 in 1900, and the rate of death from alcoholism alcohol- related accidents outstripped that of the most other areas of the world (MEADE, 2010). The Porfiriato accelerated rapid expansion of capitalism, taking advantage of the cheap indigenous labour, wide economic disparities, race distinctions and the feeble legal institutions.

The Mexican Revolution (1910-1917) was an attempt to change the directions of the brutal capitalism developed in favour of mestizos and foreigners' wealth. In fact, the Mexican Revolution, without any doubt, was a true social revolution that fundamentally transformed society, politics and culture, as Knight says:

The Mexican Revolution deserves to be included among the world's 'great' or 'social' revolutions (...) It was a 'great revolution' by virtue of the scale of the fighting, the intense popular mobilization it involved, and, over time the changes it brought about; the outcome, therefore, profoundly affected Mexico, most obviously politically, but also socially, economically, and culturally (KNIGHT, 2016, p. 1).

Another important step forward following the Revolution was the distribution of land through the ejido - community lands. This land distribution was a reward for services rendered to the Revolution by the indigenous population and a recognition of their land organization. It was also a guarantee against future rebellion and a means to attach the peasantry to the revolutionary state. The ejido grant was issued to the community, not to individuals; and it conferred usufruct, not ownership. Thereby, it was argued land grants could not be bought or sold, to the advantage of rich landlords. The conditions of the ejido opened the door to state clientelism (KNIGHT, 2016).

The ejidos produced a network of rural clientelism, - political relation based on an exchange of services with the agrarian cacique - local farmer boss - acting as the key intermediary between the mobilized peasantry and the state. Caciques would use dispossession, expulsion and repression as political weapons against indigenous members of the community, who challenged their decisions (KNIGHT, 2016). 
The revolutionary elite displaced the Porfirian oligarchy, but the new agrarian elite composed mainly of ex generals, revolutionary leaders and caudillos -politicalmilitary leaders who controlled a region or local territory- got the ownership of the best lands (CORDOVA, 1977). This resulted once again in the exclusion of the majority of rural and indigenous people, creating a landscape in which large-scale landowners exercised near complete control over rural resources and food production.

Agrarian reform, a keystone of Cardenismo, government of Lázaro Cárdenas (1895-1970), was both a means to achieve social justice and a tool for social engineering, economic development, and political control. The redistribution of 18 million hectares to 810,000 peasants changed the face of the rural society by eliminating the Porfiriatolanded estate and creating the ejido sector (BANTJES, 2011).

However, despite the rise to power of peasants and proletarians during the armed revolution, it was in the end the middle class and upper class that prevailed in achieving of the social goals of the revolution. The new bourgeoisie absorbed revolutionary elements, but it was largely the product of a fusion of old and new money and a fusion of old and new elites (BANTJES, 2011).

The National Revolutionary Party (PNR) was conceived in 1928 by Plutarco Elías Calles, who ruled Mexico between 1924-1928, but it is official presented on $4^{\text {th }}$ March 1929 under the government of Emilio Portes Gil (1928-1930), who recognized the authorship of Plutarco Elías Calles in the creation of the PNR. This political party is renamed the Mexican Revolutionary Party (PRM) in 1938 under the government of Lázaro Cárdenas (1934-1940), and in 1946 during the presidency of Manuel Avila Camacho (1940-1946) it became the PRI - Institutional Revolutionary Party-, whose name continues today. The creation of the PRI was an attempt to institutionalize political and social demands and group all caudillos under the umbrella of one political party through its corporative structure (ANGUIANO, 1975).

The corporative structure of the PRI developed from grouping the National Peasant Confederation (CNC), the Confederation of Mexican Workers (CTM) and the National Confederation of the Popular Organisations (CNOP). The PRI operated as an engine of political control, a channel for managing social demands, a machine that determined social mobility and as the centre for networking to promote clientelism (ANGUIANO, 1975). 
In this way, the PRI monopolized virtually all levels of government for 71 years (1929-2000), as well as representing a political channel to take into account the social demands without resorting to armed force, maintaining a relative social peace in the country, integrating all generals, caudillos and other political dissidents to the political system. The PRI also served as an institution to promote nationalistic propaganda that aimed to convert the Indigenous people into Mexicans with the same mestizo values through the public education system, academic institutions, and artistic and cultural productions (KNIGHT, 1990).

The creation of murals and nationalist art that exalting the indigenous culture and glorious Aztec past was quite successful:

The government commissioned huge didactic murals, which graced the walls of public buildings and were supposed to inculcate revolutionary values secularism, nationalism and progress in the hearts and mind of the largely illiterate masses. The murals of Diego Rivera thus depicted fat, despotic, and debauched priest who had connived with Spanish conquistadors in the past (KNIGHT, 2016, p. 94).

Paradoxically, the indigenous groups were once again considered an enclave for rural clientelism and the target of caciques. One of the significant consequences of the Revolution was the decision to reverse the process of social exclusion, mainly of indigenous people, by formalizing universal citizenship rights through the first Article concerning individual rights in the Constitution of 1917: "In the United Mexican States every person shall enjoy the guarantees granted by this Constitution, which may not be restricted or suspended except in cases and under the conditions established it" (MÉXICO, 1917, p. 2).

Certainly, the Constitution of 1917 gave the indigenous people the same equal rights as Mexicans, however, most the indigenous people did not speak Spanish -the national language of the country- and did not know their rights before national Courts and Tribunals. Even so, they were transformed into "farmers" and "peasants" along with non-Indigenous rural producers (VARGAS-CETINA, 2001).

The principles of equal citizenship declared formally by the Mexican Constitution was a huge achievement; nevertheless, its impact was ambiguous. On the one hand, on paper, it was a legal recognition of indigenous people providing equal political, civil and social rights. On the other hand, the indigenous people were 
relegated to a glorious past in the rhetoric of the politicians, and narrative of the PRI, but they were exploited as cheap workers or in non-qualified jobs in construction and as farmer's work peones and were forgotten in the remotes areas of country, subjugated to the will of capricious and unscrupulous local caciques.

The revolution's impact was ambiguous. Education, civil ritual, and new political institutions and practices -the party, unions, and elections- forged a lasting sense of patriotism and spawned a flowering of national culture, establishing unity in a fragmented society. However, the state was less successful in overcoming cultural inertia. Although, it succeeded in relegating the Church to a subordinate position, Mexico remained devoutly Catholic. Popular and indigenous cultures remained rooted in tradition, though the state became quite adept at manipulating "tradition" for its own purposes (BANTJES, 2011).

The "revolutionary" dimension of PRI rule thus became increasingly rhetorical: it existed in the name, in the regime's high-flown, but often hypocritical rhetoric, in school textbooks and official anniversaries, and in the continually recycled myths and symbols of the Revolution: Madero and democracy; Zapata and land reform; Cárdenas, oil, and economic nationalism. Over time, however, even these revolutionary icons were claimed by the PRI's rulers and opposition movements: Madero was exploited by the Christian-democratic National Action Party founded in 1939 (PAN), Zapata was exploited by the "neo-zapatistas" rebels in the southern state of Chiapas in 1994, and Cárdenas by the left-wing Party of the Democratic Revolution (PRD) set up in 1987 (KNIGHT, 2016).

\section{A new chapter in inequality}

The arrival of the Neoliberals ${ }^{6}$ to the Mexican government did not improve the lives of the indigenous people, quite the opposite. The privatisation of many services left the indigenous people without access to education, healthcare and sanitation services, reducing them to live under eternal poverty.

The governments of Carlos Salinas de Gortari (1988-1994) and Ernesto Zedillo Ponce de León (1994-200) were characterized by their continuous repression towards of the indigenous people of southern Mexico, particularly in Chiapas, after the uprising of indigenous people under the leadership of

\footnotetext{
${ }^{6}$ People who embrace the Neoliberalism theory, which emerge a late $20^{\text {th }}$ century revised Liberalism ideas referring to economic, political, and civil rights for individual such as private property, freedom of speech, free markets and trade, and seeks to transfer economic wealth from the hands of the state to the private sector (MEADE, 2010).
} 
the subcomandante Marcos, which coincided with the entrance of Mexico to the North American Free Trade Agreement (NAFTA) on January $1^{\text {st }}$, 1994. The movement Zapatista focused attention on the inequalities of free trade, unequal distribution of wealth and power, and exposure the living and working conditions of the indigenous people in Mexico to the world.

The indigenous movements, seeking agrarian reforms, good governance, democracy and social, cultural and economic recognition have been a constant in Mexican history; however, the most recent movement the zapatistas has often been brutally repressed.

For example, the Acteal massacre occurred on $22^{\text {nd }}$ December 1997, in which 45 indigenous people, including pregnant women and children, from Tzotzil's community were killed while attending a Roman Catholic prayer meeting. They were members of the pacifist group Las Abejas - The Bees -, based in the small village of Actealin the municipality of Chenalhó, in the Mexican state of Chiapas. The massacre was committed against of the Abejas village because of their support to the Ejército Zapatista de Liberación Nacional- EZLN (Zapatista Army of National Liberation). The massacre was carried out by the paramilitary group Mascara Roja, or Red Mask, who were sent by the PRI and local rulers, to punish and dismantle the Indigenous people of San Pedro Chenalhó, for resisting government authority and for attempting to construct their own independent government (RAMÍREZ, 2007).

The Acteal massacre was part of an undeclared war, by Gobernación, Minister of the Interior of Mexico, which involved federal and state agencies using military logic to intimidate, control and inject fear in those indigenous groups, who were intent on rebelling against the rulers of the Mexican State (RAMÍREZ, 2007). The arrival the Vicente Fox (2000-2006) to the national presidency did not improve living conditions for the indigenous people, in fact it was quite the opposite. The perception of the "Mexicans from the Nord" as white Mexicans, speaking English with North American accents and having gringo manners, educated in the United States of America, universities has been perpetuated throughout Mexican history. As the old saying, attributed to Porfirio Diaz, goes: "poor Mexico, so far from God, and so close to the United States" (EAKIN, 2007, p. 293). The stigma attached to being an indigenous person continues to this day and is strengthened by advertisements, television programs and soap operas - telenovelas. The white person is presented as an intelligent, strong and beautiful individual. The indigenous person is frequently 
portrayed as a domestic worker, who accepts his/ her social class position with humility (RAMÍREZ et al., 1991).

Today, in Mexico, even if the majority of the population are mestizos, they continue reproducing schemes of discrimination and stigmatisation towards indigenous people. Mestizos also continue attributing superiority to Europeans and admiring white physical features. Mexican television is full of blonde people who are portrayed as superior in spiritual manner, sweet, modest, sensible, "good taste", and well-educated. On the opposite, indigenous people are portrayed on television and in advertising as morons, poor and ignorant, alcoholic, or aggressive (ACOSTA, 2008). For example, La india María - The indigenous Maria - a Mexican comedy icon of the seventies depicts an indigenous woman as ignorant and open to ridicule. This character, along with others in Mexican TV and cinema, reinforces the negative stereotypes of indigenous people.

The social imaginary ${ }^{7}$ that Mexican people have in regard to the indigenous population is one of poverty and social exclusion. In geographical terms, the big Mexican cities reflect the inequality and social exclusion of the indigenous people. Marginalization of Mexico City's native population is a deep-rooted problem, formed by a historical process of segregation, supported by the negative and prejudicial colonial representation of "indigenous" people. Until now, the "native issue" has mostly affected the peripheral regions of Mexico: the depressed, rural areas, where the native population has been forced to live because of colonial policies. Today, indigenous marginality is increasingly becoming an urban matter due to at least five decades of intense migration waves from rural areas to metropolitan Mexico City. Along with contemporary "ethnicization", specific native group that have been settling in the city for decades yet are still considered "outsiders" and "deterritorialized". In the "land of inequalities", as a report defines Mexico City, chances of integrating native immigrants into urban society are very low. Their extreme poverty and the cultural resistance towards them exacerbate poverty and their marginalized conditions (SAPORITO, 2011).

According to Saporito, an Italian architect and urban planning, native Mexican indigenous people are found in informal settlements referred to areas for

\footnotetext{
${ }^{7}$ The social imaginary is used in the sense of the philosopher Cornelius Castoriadis to name the social representations incarnated in the institutions: "the social imaginary is, primordially, the creation of signification and creation of the images and figures that support these significations (...) The social imaginary exists as social-historical doing/representing; as such, it institutes and is obliged to institute the 'instrumental condition' for its social-historical existence” (CASTORIADIS, 1998, p. 222- 225).
} 
"the excluded society", where they work as hawkers or domestics, settling in selfbuilt colonias populares or colonias perdidas or squatting in the crumbling dwellings of the city centre. Ethnicity plays a fundamental role in determining indigenous exclusion, even within Mexico City's "marginalized society". In fact, native communities represent the "poorest among the poor". Part of this exclusion originates from the common cultural prejudice that often produces a conflicted relationship between indigenous and non-indigenous groups (SAPORITO, 2011).

The geographical and social exclusion of indigenous people is strengthened by prejudicial stereotypes, and State policies that fail to integrate these groups into the rest of the society. Walls divide poor boroughs from rich ones, and the rich people are able to use their power and influence to hire private security, which separates them from the indigenous population and does not address the root cause of inequality.

In recent years, the governments from Felipe Calderón Hinojosa (200620012) to Enrique Peña Nieto (2012 - predicted until July 2018) have been defeated by the brutal violence of organized crime. According to Mexico's annual Drug Violence Report (2015) there were 22,480 people murdered in drug related issues in Mexico in 2011, 15, 649 in 2014 (Drug Violence Report, 2015), and 20, 878 from January to October 2017, meaning that every 18 minutes was recorded a new killing (MELÉNDEZ, 2017).

Mexico became home to a bloody, nationwide drug war after the thenPresident Felipe Calderón announced in December 2006 that the government would crack down on drug cartels and go after their leaders. This situation has had a huge impact on the indigenous population as they are the most vulnerable groups in society in terms of access of the rule of law, living in isolated regions, having no professional qualification, high levels of illiteracy, high levels of social and economic exclusion. Indigenous people are exposed to a double violence. On one hand, they are forced by the narcotrafficant groups to cultivate drugs in exchange for keeping a relative peace in their communities, but on the other hand they are the first groups to be repressed by the army on the grounds of drug cultivation, without any respect of human rights.

There are innumerable cases of human rights violations perpetrated against indigenous communities in Mexico, some become public knowledge, and others go unnoticed by the rest of the Mexican and foreign society. For example, on November 13, 2006 under the government of Felipe Calderón, the former governor of the 
State of Chiapas Pablo Salazar (2000-2006), instructed about 40 people from the indigenous community of Tzeltal, called the New Palestine, and about 300 members of the Police to use firearms to attack families of Tzeltales, Tzotziles and Choles living in the community of Viejo Velasco Suárez in Ocosingo, the State of Chiapas. The attack left seven dead, two missing and displaced 20 men, eight women, five boys and three girls. Petrona Nuñez González, a survivor of the slaughter, died in 2010, as a result of post-traumatic stress. 36 people who fled the slaughter were left displaced from their homes, in a state of vulnerability, their political and human rights violated (BELLINGHAUSEN, 2014).

There was also a brutal rape of women in the community of Atenco, in the State of Mexico, on 4 May 2006, when Enrique Peña Nieto was governor of the region (2005-2011), and Vicente Fox was president of Mexico (2000-2006). Police and members of the army arrested more than 200 locals and committed brutal sex attacks on women as a means to dismantle a protest by Nahuatl peasants flower sellers, angry at being denied access to the Texcoco local market (FAZIO, 2006).

They said they were hooded or covered their faces with their clothes; they stripped violently; they were verbally abuse, they subjected them to the worst treatment and sexist insults ("whores", "bitches", "daughters of bitches", "assholes"), while viciously beating them all over their body; they touched their genitals and anus with brutality; in many cases they penetrated the women with fingers and/or objects, and in one with the penis; several were forced to perform oral sex in a riotous manner; for several hours were subjected to physical, psychological and moral torture; they were threatened to death; they kept them in communicated and in a state of physical and mental helplessness, and all were denied medical and legal assistance, increasing their vulnerability (FAZIO, 2006, p. 22). 
Another case in point is in the Sierra Tarahumara, in the State of Chihuahua, to the northern of Mexico, where indigenous communities called rarámuris have committed collective suicides due to the famine that have existed in the region, exacerbated by the presence of criminal groups and high levels of corruption:

Indigenous women, when they have 4 or 5 days without being able to nourish their children, became depressed. The anxiety and depression drove whole families to commit suicide. Recently, 50 women and men with nothing to eat launched themselves over a precipice. Others hanged themselves (SIN EMBARGO, 2012, p. 3).

The same situation is registered in the indigenous communities of Napuchi, Wisarorare, Baquiachi and Pasigochi, in the north of the country. While the former governor of Chihuahua and ruler from the PRI, César Duarte Jáquez (2010-2016), and his family and political group have enjoyed a luxurious way of life, Duarte Jáquez was allegedly involved in corruption and impunity (CARDOSO, 2016).

Another illustration demonstrating the impunity and the collusion of national and local government in the repression of indigenous people was the massacre of 43 students in the Mexico's southern Guerrero state on 26 September 2014, under the government of Enrique Peña Nieto. The massacre took place when more than 100 students from the Raúl Isidro Burgos Rural Teachers College of Ayotzinapa in Tixtla, a town in Guerrero state, travelled to Iguala to hold a protest against what they considered discriminatory hiring and funding practices by the government. They were intercepted by the local police, who arrested 43 of the school's students who have not been seen since (ALEXANDER, 2015).

According to official sources, the students were abducted on the orders of the mayor of Iguala, José Luis Abarca Velázquez (2012-2014), who was concerned that they would disrupt an event in his town. The students were then handed over by corrupt police to members of Guerrero's drug gangs, who are said to have murdered the students and burnt their bodies in a rubbish dump. Two hit men working for the drugs cartel said that they had piled the bodies on bonfires (ALEXANDER, 2015). Since then, the government of Peña Nieto has tried to close the case on several occasions; however, national and international human rights organizations, as well as the entire mexican society, have opposed Peña Nieto's will. The fate of the students is seen as being a symbol of the corruption, violence and impunity that has long 
besmirched Mexico although, the impunity goes beyond this case, and unfortunately indigenous people continue being the target of innumerable abuses.

\section{Conclusions}

Mexico continues to be trapped between its colonial past and a form of rule based on repression, mutilation, torture and corruption. A Rule of law based on equality of all races must be implemented, if the social exclusion of indigenous people is to be overcome. Currently, $21.50 \%$ or 25694928 almost 25.7 million people out of the total of 119530753 inhabitants in Mexico consider themselves to be indigenous (INEGI, 2015).

Mexico is one of the most mestizos countries in the world, with a mixture of races that goes beyond the blond. This mixture is extended to culture, food, language and religion. It is time for the Mexico profound composed of the indigenous population and the Modern Mexico driven by the mestizos to rejoice in their differences and similarities.

The modern Mexico needs to accept, respect and include indigenous people as equal citizens not only in paper, but in also in daily life. The distinction of racial, ethnic group and caste are social constructions that have served to both oppress people and isolate them. Colonial regimes manipulated, as well as created, such identities (LOOMBA, 2015). Therefore, our duty is to reverse those identities associated with marginalization, exclusion and social and economic inequality.

The conditions indigenous people endure are as bad as they were in the early nineteenth century. They continue living under "a persistent exclusion pattern", where they have less opportunity to get a quality and stable job. An indigenous person is 2 -3 times less likely to get a good job than a non-indigenous person (GONZÁLEZ, 2016). In terms of social mobility, a child born to indigenous parents is "notoriously" likely to grow up in poverty. In Mexico the probability rises between 11 and 9 per cent (GONZÁLEZ, 2016). Regarding, family income, poverty affects $43 \%$ of indigenous families, which is more than the double that of a nonindigenous family (GONZÁLEZ, 2016).

Indigenous people continue living in a "culture of poverty". Poor agricultural returns, the consequences of climate change, organized crime, impunity, corruption and inefficient governance have forced thousands of ejidatarios - people who are allowed to hold and work an ejido- to abandon their plots to work in Mexican cities or to emigrate to the United States of America. Women and girls enter the work force as maids, cooks, nannies, laundresses, street vendors, and prostitutes. 
Indigenous children are often abandoned to the streets, where they become victims of sexual slavery, human organ trafficking, or are turned into human merchandise sold for adoption or slavery.

Mexican politicians, financial elites as well as the rest of the population must work together in order to fully integrate indigenous groups. Instead of exploitation of the indigenous population and the exhaustion of finite natural resources and the destruction of land for short-term gains, the future should be built on collaboration and respect for people and the natural environment. It should celebrate the strength of mestizaje, the realization that all people, men and women, all races and all ethnic strains, have created a remarkably rich history (MEADE, 2010).

One important way to achieve a harmonious future is to relay and respect the rule of law and overcome any administrative and political inefficiency that may cause social fragmentation, human rights violations and an inability to support human security. Furthermore, it is important to be aware of the labels, stigmas, and stereotypes linked to indigenous people, which act as a social mechanism to degrade this group. Understanding degradation lets us see how structures of social power can actually affect the psychology of individuals (EWEN, 1998). Particularly, indigenous people who have been overexploited and disenfranchised for centuries. Cultural integration is a huge challenge that Mexico must address in the years ahead. if it wants to achieve sustainable development and reduce the gap between rich and poor, as inequality does not harm only the poor, but also middle and upper classes. The poor struggle for survival, and the rich suffer from emotional problems, anxiety, stress, fear to be attacked, kidnapped or robbed by disadvantaged people (WILKINSON and PICKETT, 2010). Overcoming, the difficulties of the colonial past, and ensuring the indigenous people share equality with all other races should be at the top the agenda of the State policies for the current and future governments of Mexico. 
Nubia Nieto é PhD. em Geopolitica na Universidade PantheonSorbonne Paris I e Pesquisadora independente. E-mail: continents. sky@gmail.com.

\section{Referências}

ACOSTA, Mariclaire. Los estereotipos de la mujer mexicana en las fotonovelas. In: ESPINASA, José María (ed). Antologia. Revista Diálogos, El Colegio de México, 2008, p. 179- 184.

ALEXANDER, Harriet. What has happened to the missing Mexican students, and why does it matter? The telegraph, The United Kingdom, 2015.

ANGELES, Luis; NEANIDISY, Kyriakos C. Colonialism, elite formation and corruption. Growth and Business Cycle Research \& Economic Studies. n. 144, University of Manchester, 2010.

ANGUIANO, Arturo. El Estado y la política obrera del cardenismo. Era, 1975.

BANTJES, Adrian A. The Mexican Revolution. In: HOLLOWAY, Thomas (ed.) A companion to Latin American History, The United Kingdom: Wiley-Blackwell, 2011.

BELLINGHAUSEN, Hermann. Acusan impunidad a 7 ańos de matanza de indígenas en poblado de Ocosingo, La jornada, México, January 30, 2014.

CARDOSO, Guillermo. Saquean y endeudan sus estados, Unomásuno, México, November 21, 2016, p. 6-7.

CASTORIADIS, Cornelius. The imaginary Institution of Society. Translated by Kathleen Blamey, The MIT Press Cambridge: Massachusetts, 1998. This work originally appeared in French under the title L'institution imaginaire de la société, Paris, France: Editions du Seuil, 1975.

CASTRO, José Esteban. Water, power and Citizenship. Social struggle in the Basin of Mexico. United Kingdom: Palgrave- Macmillan, 2016.

CÓRDOVA, Arnaldo. La formación del poder político en México, México: Era, 1977.

EAKIN, Marshall. The history of Latin America. Collision of cultures, Palgrave- Mamillan, 2007.

EWEN, Lynda Ann. Social statfification and power in America. A view from Below. General Hall, 1998.

FAZIO, Carlos. Atenco y la tortura sexual. La Jornada, México, June 5, v. 22, n. 7823, p. 22, 2006.

FERGUSON, Niall. Civilization: The west and the rest. Allen Lane-Penguin Books, 2011.

GALEANO, Eduardo. Open Veins of Latin America, Serpent's Tail, 2009.

GONZÁLEZ AMADOR, Roberto. Sufren pobreza 43\% de hogares indígenas en AL: BM, La Jornada, February 17, 2016, p. 28

INSTITUTO NACIONAL DE ESTADÍSTICA Y GEOGRAFÍA, (INEGI). Encuesta Intercensal 2015. Panorama sociodemográfico de México 2015, México, INEGI, 2015. 
KNIGHT, Alan. Racism, Revolution, and Indigenismo: Mexico, 1910-1940. In: GRAHAM, Richard (ed.) The Idea of Race in Latin America, 1870-1940, Austin Texas, USA: University of Texas Press, 1990, p. 71-113.

KNIGHT, Alan. The Mexican Revolution: a very short introduction, Oxford University Press, 2016.

KOTHARI, Uma. Spatial practices \& imaginaries. Experiences of Colonial Officers \& Development Professionals. In: DUFFIELD, Mark; HEWITT, Vernon. Empire, development \& colonialism, the past in the present. South Africa: James Currey, 2009, p. 161-175.

LEWIS, Oscar. The children of Sanchez: Autobiography of a Mexican Family, Harmondsworth, 1961.

LOOMBA, Ania. Colonialism/Poscolonialism. Routledge, 2015.

MARTÍNEZ, María Elena. Genealogical Fictions. Limpieza de Sangre, Religion, and Gender in Colonial Mexico, Stanford University Press, 2008.

MARTÍNEZ COBO, José R., Study of the problem of discrimination against indigenous populations, New York, United Nations. Sub-commission on Prevention of Discrimination and Protection of Minorities, 1987.

MEADE, Teresa. A history of Modern Latin America. 1800 to the Present. The United Kingdom: John Wiley \& Sons ltd, 2010.

MELÉNDEZ, Roberto. 2017, año de pesadilla. Unomásuno, v. 14454, n. 28, p. 8-9, 2017.

MÉXICO. Constitución Política de los Estados Unidos Mexicanos, que reforma la de 5 de febrero de 1857. México: Diario Oficial, Tomo v. 4. Época, n. 30, Lunes 5 de febrero, 1917, p. 149-161.

NIETO, Nubia. La socialización de las élites políticas mexicanas a través de la corrupción. Análisis político, Bogotá, Colombia, v. 25, n. 71, p. 165-181, 2011.

RAMÍREZ QUIRÓS, Ileana; ABRAMAVA, Miraiam; DAMASCO FIGUEREDO, Marcia. Detrás de bastidores: un estudio de los mensajes producidos, Centro Interamericano de Documentación e Información Agricola (CIDIA), Proyecto mujer y comunicación (IICA/ASDI), 1991.

RAMÍREZ CUEVAS, Jesús. La masacre de Acteal. Culminación de una política de Estado contra indígenas, La journada, 2007.

RAMÍREZ, Susan. Institutions of the Spanish American Empire in the Hapsburg Era, chapter 7. HOLLOWAY, Thomas. A companion to Latin American History, United Kingdom: WileyBlackwell, 2011.

SAPORITO, Emanuela. The marginal communities: social and ethnic segregation of the native population. Italy: Politecnico di Milano, dipartamento di Architettura e Planificazione. 2011.

SIN EMBARGO. Rarámuris se suicidan por hambre en la Sierra Tarahumara, denuncian autoridades y activistas, México, enero 15, 2012. Disponível em: <http://www.sinembargo.mx/15-012012/121025> Acesso em: 7 jul. 2014.

TERRACIANO, Kevin. Indigenous peoples in Colonial Spanish America. In: HOLLOWAY, Thomas (Ed.) A companion to Latin American History. Wiley-Blackwell, 2011.

THERBORN, Göran. The killing fields of inequality. Polity Press, 2013.

VARGAS-CETINA, Gabriela. Postcolonial sites and markets: Indigenous organizations in Chiapas. Journal of Critical Postmodern Organization Science, Mexico, v. 1, n. 3, p. 68-80.

2001. 
150 | Nubia Nieto

WENDT, Alexander. Collective Identity Formation and the International State. American Political Science Review, v. 88, n. 2, p. 384-396, 1994.

WILKINSON, Richard; PICKETT, Kate. The Spirit Level. Why equality is better for everyone. London, Penguin, 2010.

YOUNG, Robert. Postcolonialism. Oxford University Press, 2003.

Texto recebido em 17 de julho de 2017. Aprovado em $1^{\circ}$ de março de 2018. 